\title{
Sounding like a Mad Hatter: Ernst-Ludwig Petrowsky and the Beginnings of Jazz Experimentalism in East Germany
}

\section{Harald Kisiedu}

This article examines the rise of jazz experimentalism in the German Democratic Republic (GDR) with a focus on one of its major proponents: multi-reedist and improviser Ernst-Ludwig Petrowsky. Petrowsky's development and engagement with post-1950s jazz practices took place within the context of politico-aesthetic debates that were decisively shaped by the Cultural Cold War. Focusing on the conditions of production in a state socialist system, I explore the difficulties Petrowsky and other jazz experimentalists faced under the ideological constraints imposed by GDR cultural policy makers during the height of the Cold War. Emphasizing the conditions in the East German state socialist system, I reconstruct the critical reception of post-war jazz in the GDR and discuss Petrowsky's engagement with African-American experimentalism during the 1960s. Moreover, this essay goes beyond the convenient oppression and decadence narratives commonly associated with jazz in the GDR by identifying the complex ways in which internal supporters and detractors, responding to cultural pressures from the West, engaged in debates about the music, thereby complicating the notion of authoritarian shutdown.

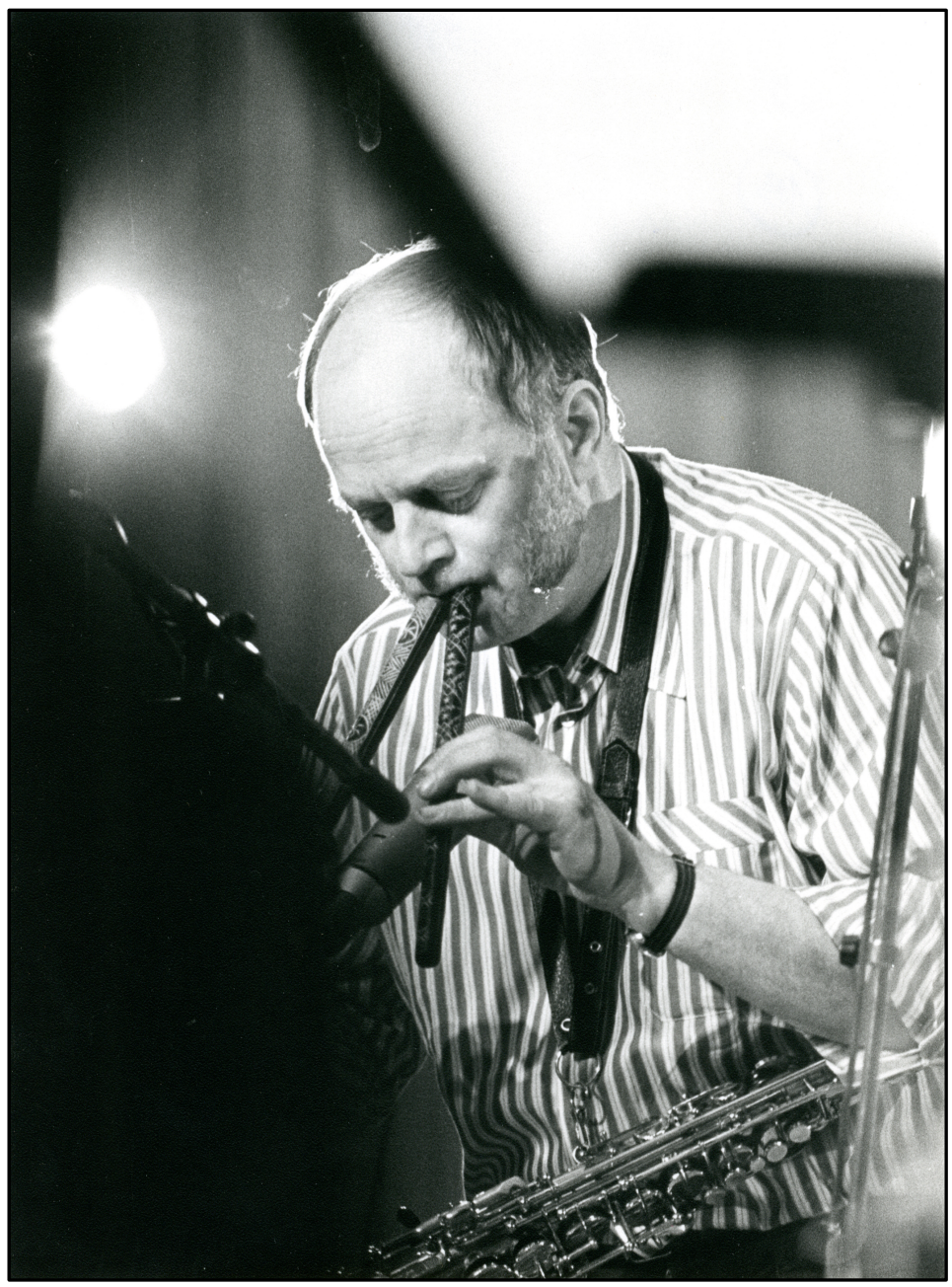

Ernst-Ludwig Petrowsky (Klaus Muempfer)

Ernst-Ludwig Petrowsky was born in the town of Güstrow on December 10, 1933 to a mercantile family. As a child, he was influenced by military marches widely performed during the National Socialist Regime. Petrowsky remembers the first years following the regime's downfall as ultimately unshackling, as they allowed for his first encounter with jazz in the guise of the Glenn Miller Orchestra's hugely popular 1939 recording "In the Mood": "For me, as opposed to Nazi military marches, that was such liberation and it grabbed me like a type of infection. I was no longer really in control of myself." 
He soon developed a fascination with jazz, which for him was "like a cry that you wanted to answer" (Noglik, Jazzwerkstatt 324). Even though at that time he had an aversion towards European classical music, Petrowsky sang in both a school and a church choir and occasionally performed with the latter on the violin. Prior to his encounter with jazz, his parents insisted he play the instrument in order to instill him with a sense of artistry. After meeting classical musicians from the local church and theatre orchestras, the young Petrowsky took an immediate liking to them, as they seemed emblematic of an alternative world: "They were already different from the average citizens that I knew otherwise. I went so far as to think, 'No matter what they play I want to be around them. That is where I want to be. That is my world as opposed to the petit bourgeois one'" (Petrowsky).

Petrowsky began to teach himself the saxophone at the age of seventeen, and shortly thereafter met trombonist, pianist, composer, and arranger Eberhard Weise, a member of Güstrow's theatre orchestra, who shared Petrowsky's fascination with jazz and from whom he received crucial impulses in terms of music and discipline. Meanwhile, he studied clarinet with Gottfried Wolf, who played in the same orchestra and Petrowsky and Weise formed a combo in 1955. In the following year, Petrowsky attended the Hochschule für Musik Franz Liszt Weimar, where he obtained instruction on violin and on piano through the academy's music education program. During this period, Petrowsky immersed himself in the sounds of the cool and West Coast jazz movements, especially the music of Lennie Tristano, Lee Konitz, Chet Baker, and Paul Desmond (Noglik and Lindner 119).

At a youth camp at the seaside health resort Graal-Müritz, Petrowsky met Polish pianist and composer Krzysztof Komeda. During the 1960s Komeda not only emerged as a key figure on the Polish jazz scene but, as Ekkehard Jost has maintained, also kicked off the first attempts at "European musicians' partial emancipation from their American father figures" (Jost 213). ${ }^{2}$ Before his untimely death in 1969, Komeda would also gain notoriety beyond the jazz world as the composer of the scores for Roman Polanski's feature films Knife in the Water, Rosemary's Baby, and The Fearless Vampire Killers. After performing together at nightly sessions, Komeda asked Petrowsky to join his band in Poland, which, however, did not materialize since the saxophonist sought to continue his studies at the Musikhochschule in Weimar (Noglik and Lindner 117-18).

In 1957, after moving to the town of Görlitz, Petrowsky and Weise co-founded the Orchester Eberhard Weise, a modern jazz ensemble modeled after Miles Davis's short-lived late-1940s nonet. During this period, Weise's orchestra was the only ensemble to perform exclusively contemporary jazz in the GDR. As musicologist Bert Noglik has observed, "regarding the commitment to contemporary jazz the band occupies a special position within the 1950s GDR" ("Hürdenlauf" 210). In a 1958 typescript, Petrowsky delineated the ensemble's idealistic impetus: "The Orchestra Eberhard Weise is jazz music's consequential and substantive impact on some young people who are more serious about things than to be able to afford to deal with musical and spiritual problems only in passing, from the perspective of a safe bourgeois existence" (qtd. in "Hürdenlauf" 211).

As Petrowsky and his bandmates would soon find out, their musical performances during the latter half of the 1950s not only didn't appeal to audiences, but also faced considerable resistance on the part of audience members. The Weise Orchestra sought to make concessions to the preferences of their East German audiences by incorporating jazz versions of then-popular songs such as Robert V. Barron's and Bert D'Lugoff's "Cindy, Oh Cindy" during their performances, which usually would take place at dance nights. As Petrowsky has remarked, these compromises were to no avail: "We had these starting difficulties. Everywhere we played we practically caused sheer horror ... . There was no jazz scene. Those were dancing parties. People only wanted to dance, essentially like nowadays" (Bratfisch, "Montreux" 126).

The lack of acceptance of the Orchester's music as witnessed by Petrowsky has to be viewed within the wider context of what musicologist Fred K. Prieberg has denoted as "the volatile history of jazz in the GDR" (325). During the period between June 1945 and the GDR's establishment on October 7, 1949, the Soviet Military Administration in Germany encouraged jazz in its Occupation Zone, as the Soviet authorities viewed it as "anti-fascist" due to its suppression and designation as "degenerate" by the National Socialist Regime (Schmidt-Rost). Under the supervision of the Soviet Military Administration the record label and publishing company Amiga, which became state-operated in the GDR, was established and began to release jazz recordings by January of 1947 (Noglik, "Linden-Blues" 421). The Soviet Military Administration supervised and supported the establishment of radio orchestras in its Occupation Zone, such as the Radio Berlin Tanzorchester, directed by trombonist and composer Walter Dobschinski, and the Tanzorchester des Senders Leipzig, directed by saxophonist Kurt Henkels. In August 1948, Henkels's orchestra, which soon after its establishment became the premier big band in the Soviet Occupation Zone, recorded a piece composed and arranged by its clarinetist Rolf Kühn, titled "Rolly's Be-Bop." Kühn's composition represented arguably the earliest documented engagement of German musicians with the innovations advanced by Charlie Parker and Dizzy Gillespie. According to music historian Rainer Bratfisch, "'Rolly's Be-Bop,' however, provoked intense discussion due to its modernness" ("So viel Anfang” 24). 
The discussions about the aesthetic validity of "modern jazz" that took place in the Soviet Occupation Zone were accompanied by intensifying ideological divisions that were themselves informed by the onset of the Cold War. Insurmountable differences between the major powers regarding the "German question" had already surfaced during the March/April 1947 Moscow Conference of Foreign Ministers. As historian Andreas Malchya has argued, "accordingly they intensified their endeavors to integrate the parts of Germany occupied by them into their spheres of interest and to match the political conditions with their own social concept of order" (17-18). Already in his "The Sinews of Peace" speech given on March 5, 1946, at Westminster College in Fulton, Missouri, Churchill had stated, "now the Soviet Government tries, by separate action, to build up a pro-Communist Germany in their areas" (Churchill 7291). As historian Hermann Weber has asserted, "the US foreign policy with the 'Truman Doctrine' from Spring 1947 and then with the Marshall Plan boiled down to a confrontation with the USSR, whereby the doctrine of 'containment' supplied the ideological background" (92).

In September 1947, Andrei Zhdanov, Second Secretary of the Communist Party of the Soviet Union, delivered the keynote speech on the occasion of the founding of the Information Bureau of the Communist and Workers' Parties, in which he delineated his doctrine of "the two camps." In his speech Zhdanov ascertained, "the division of the political forces operating in the international arena into two major camps: the imperialist and anti-democratic camp, on the one hand, and the anti-imperialist and democratic camp, on the other" (Zhdanov). The deepening ideological divisions between the Soviet Union and the US also began to afflict the arts and aesthetic discourse surrounding them. Of crucial significance in this context was the notion of socialist realism. According to historian David G. Tompkins, "Stalin and leading cultural figures like Maxim Gorky formulated the term itself in the spring of 1932" in the aftermath of the Cultural Revolution of 1928-1931 (Tompkins 17). Already in a 1934 speech delivered in front of the First Congress of Soviet Writers Zhdanov had formulated his notion of socialist realism, whose method he delineated as a way to "depict reality in its revolutionary development ...combined with the ideological remolding and education of the toiling people in the spirit of socialism" (qtd. in Tompkins 17). In the wake of their proclamation, the ideas advanced by Zhdanov became a state doctrine in the Soviet Union (Jungmann 77).

According to musicologist Martin Lücke, "Zhdanov authored four well-known cultural resolutions for literature, theatre, film, and music between 1946 and 1948," of which "each addressed the fight against allegedly increasing influences from outside the Soviet Union and against capitalism in the arts" (93). In his 1948 resolution about music, which was aimed against Vano Muradeli's opera The Great Friendship and the works of Dmitri Shostakovich, Sergei Prokofiev, and Aram Khachaturian, Zhdanov campaigned against socialist realism's ideological antipode, which he denoted as "formalism." Zhdanov conceived of formalism as an aesthetic stance that gave formal aspects and abstraction priority over ideas, while disregarding art's socially relevant content. He viewed these characteristics as symptomatic of a perceived Western decadence. In his 1948 resolution he identified the ostensible dangers emanating from musical modernism, which were to have important implications for the reception of post-war jazz in state socialist systems:

Characteristic of this music are the negation of the basic principles of classical music; the glorification of atonality, dissonance and disharmony, which are allegedly an expression of progress and innovation in the development of the musical form; further, the refusal of the important basis of a composition like melody; the devotion to the abstruse, neuropathic combinations which transform music into a cacophony and a chaotic accumulation of tones. ... This music strongly follows the spirit of the present modernistic music in Europe and America, which reflects the mud of bourgeois culture and a complete denial of musical art. (qtd. in Lücke 93-4)

As music scholar Irmgard Jungmann has argued, "Zhdanov's deliberations would become the basis for a mostly nondisputable doctrine of aesthetic debates in the GDR as well" (78). The extent to which these aesthetic debates, which began to set in by autumn 1948, were informed by Zhdanov's ideas is exemplified by the scholarly discourse around jazz in the GDR's early years. According to music historian Michael Rauhut, "in February of 1950, the Soviet Union intervened with a frontal assault on 'abhorrent American jazz' and demanded that the SED (Socialist Unity Party - the ruling regime in East Germany) follow the party line" ("Voice" 93). In an article for the East German newspaper Tägliche Rundschau, Soviet cultural commissars S. Timofejew and W. Nicolajew declared, "The resolute battle against the tasteless American jazz music (Boogie-Woogie etc.) and against the formalistic direction in the music, so hostile toward the Volk, is necessary, as is the nurturing of the traditional German classical and folk music and the expounding of the musical classics from all over the world, of which, as is well known, not one composer is an American" (qtd. in "Voice" 93). Timofejew's and Nicolajew's remarks are reflective of a Stalinist anti-jazz campaign that linked nineteenth century tropes of cultural nationalism with the above notion of formalism, and framed jazz in terms of a sonic weapon to which they attributed corrosive qualities.

By the early 1950s, Zhdanov's notion of formalism had palpably shaped the discourse of top-level cultural policymakers in East Germany. As historian Dietrich Staritz has stated, "in March 1951 the Central Committee had concerned itself with the situation of the arts and had detected almost everywhere 'formalism'" (72). The Central Committee's resolution of the $5^{\text {th }}$ Plenum of the Sozialistische Einheitspartei Deutschlands (SED) confronted the 
issue of formalism in no uncertain terms: "Formalism's most significant characteristic is comprised of the endeavor, under the pretense or the misguided intention, to develop something 'entirely new,' to break completely with the classical cultural heritage. This brings about the uprooting of national culture, the destruction of a sense of national identity, promotes cosmopolitanism, and denotes direct support for the war policy of American imperialism" (Jäger 38).

Various musicologists, who by April 1951 were organized in the Verband Deutscher Komponisten und Musikwissenschaftler (Union of German Composers and Musicologists), played a prominent role within these debates. The Union's umbrella organization was the cultural mass organization Kulturbund der DDR (Cultural Association of the GDR). Georg Knepler emerged as arguably the most prominent detractor of jazz within the field of musicology, playing, in the words of Ekkehard Jost, "a very inglorious role in the debate about jazz" (214). Knepler was not only the GDR's preeminent music scholar but also the rector of the Deutsche Hochschule für Musik in East Berlin. On the occasion of the April 1951 founding conference of the Verband Deutscher Komponisten und Musikwissenschaftler, Knepler gave a talk in which he supplemented the presentation of composer and musicologist Ernst Hermann Meyer, who, in the words of David G. Tompkins, was "the most important figure for propagating socialist realism in the GDR" (20). From the outset, Knepler referenced Meyer and declared that "under certain circumstances music can also be a tool for preparation for war and that nowadays in many cases it clearly is" (Knepler 56). Drawing upon ideas advanced by J. S. Bach's immediate predecessor as Thomaskantor Johann Kuhnau, Knepler asserted that one of music's oldest functions was to divert "from the most important things of the day" (56). For Knepler, imperialism had perfected music's function of diversion. He elaborated on the dangers associated with music's seductive power: "Music has the ability to make very plausible and very imposing what it emphasizes. It possesses so to speak great power to impress and to propagate" (57).

Knepler singled out US jazz as being especially culpable within the alleged scheme of diversion. To illustrate his assertions Knepler confronted his audience with Stan Kenton's 1946 recording of "Fantasy," which he introduced as an instance of "Progressiv [sic] Jazz." Delivered with the gravitas of professorial authority, Knepler's verdict was damning: "This is music which represents chaos, which is chaos, which is not only preparation for war but is war. This is an attempt to smuggle war into peoples' brains. You noticed how this is done. These are mere shreds of melodies. What resembles melodic clichés gets ripped up and disrupted. These are harsh dissonances. It is the relentless hammering rhythm. It is the unnatural utilization of instruments" (57).

During the 1950s the SED's cultural policy guidelines concerning jazz were subject to considerable changes of course, which were themselves, to a certain extent, responses to policy shifts that took place in the Soviet Union following Stalin's death in 1953. As musicologist Michael Rauhut has remarked with regard to the history of jazz in the GDR during the 1950s: "It presents itself as the up and down between state recognition as far as partial funding (media productions, forums, events, and much else) and official damnation up to massive repression (defamation, ban, criminalization etc.)" (Beat 20). In the wake of Stalin's death East German jazz proponents countered the official reading of jazz as a propagandistic tool of imperialism consistent with the SED's dissociation from Western capitalist culture by arguing that some forms of jazz and African-American music were in fact an authentic expression of the oppressed black working class and were therefore imbued with an oppositional potential regarding the anti-imperialist struggle. As Rauhut has argued, "African-American music was destined to become a 'second culture' in the sense of Lenin, both through its proletarian roots and through the cross of racism" ("Voice" 97-8).

Instrumental for bringing about this "recoding," by which "African-American musicians were celebrated as fighters for the civil rights of the oppressed" was political scientist, journalist, and dissident Reginald Rudorf (Schmidt-Rost). In the words of historian Uta G. Poiger, Rudorf was "the most outspoken" voice among those who "sought to make jazz officially acceptable" in East Germany ( "Searching" 87). ${ }^{3}$ During the 1950s Rudorf worked tirelessly toward the valorization of jazz through radio broadcasts, lectures, and journal articles. Already, in a 1952 article, Rudorf outlined his ideas about the history of jazz, which, informed by the notion of formalism, he essentially framed as a history of corruption. He denoted the music that emerged towards the late nineteenth and early twentieth century in New Orleans as "Urjazz" since "in this authentic urban folk music of the Negroes, jazz, the blues is the lamenting message about the dreadful life of the exploited" (Rudolf 248). For Rudorf, beginning in the 1920s the culture industry's commercialization of hitherto "authentic" jazz set in and caused the music's corruption, which he viewed as symptomatic of US capitalism's intrinsic decadence. In a 1954 article, Rudorf raised the charge of formalism against the bebop movement, as he identified "nihilistic tendencies" in Charlie Parker's playing (Rudorf 93). He maintained, "in 'modern jazz' there is simply a 'unity' between decadent content and decadent form" (93). 


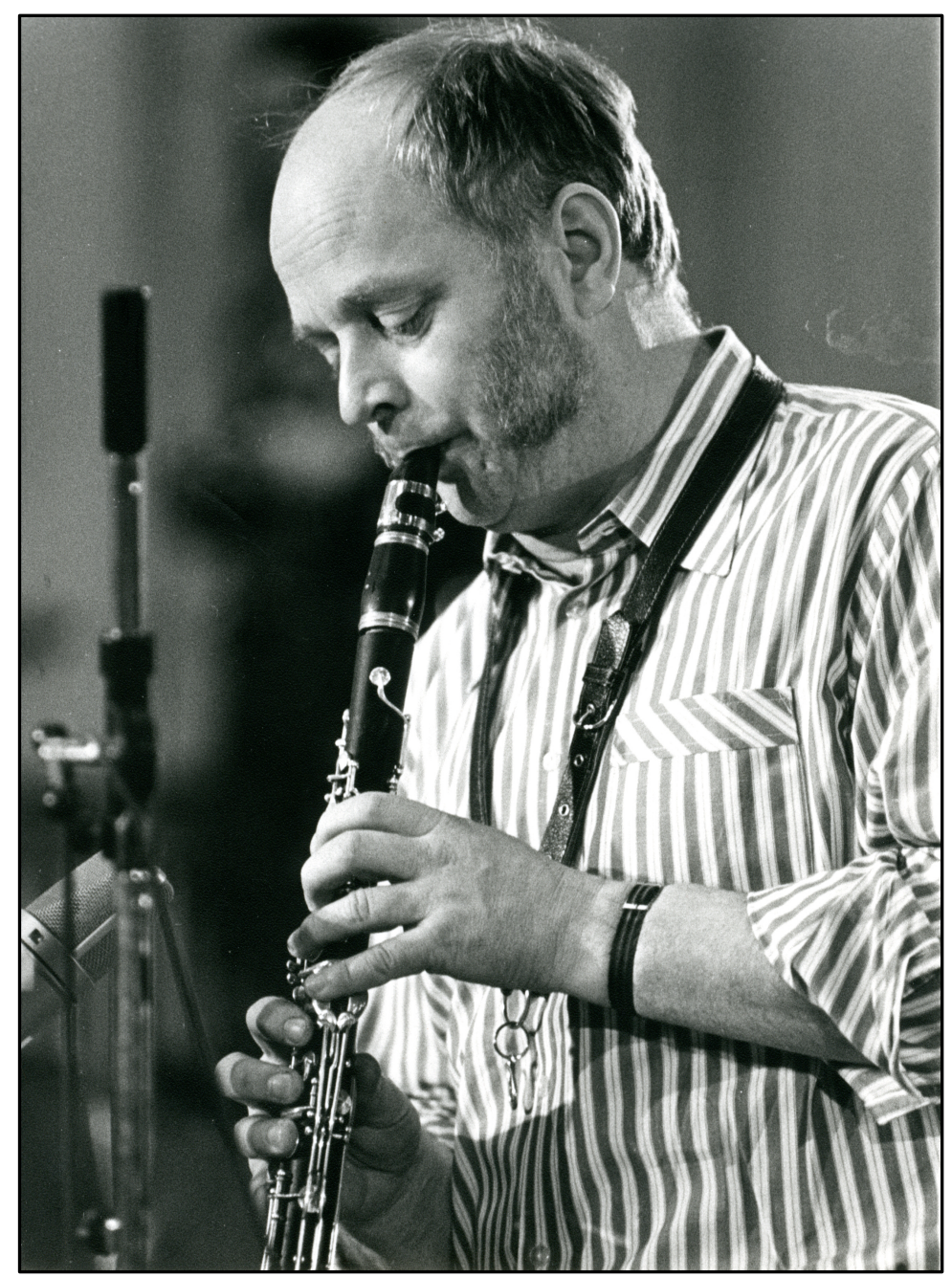

Ernst-Ludwig Petrowsky (Klaus Muempfer)

After Petrowsky had worked with the Tanz- und Schauorchester Max Reichelt beginning in 1960, he co-founded the Manfred Ludwig Sextet with baritone saxophonist Manfred Schulze in January 1962. The group included trumpeter Heinz Becker. Born on May 28, 1938 in Dresden, Becker became intrigued with the playing of Chet Baker and started taking lessons from a trumpeter at a local theatre. ${ }^{4} \mathrm{He}$ joined a youth dance orchestra that was modeled after the Count Basie band, and eventually became one of the founders of an orchestra, whose instrumentation was identical to that of the Dresden Tanzsinfoniker led by pianist and composer Günter Hörig. Encouraged by the orchestra's success, Becker and some of his colleagues sought to pursue professional music careers, which in the GDR as a general rule was inextricably linked with the receipt of a Spielerlaubnis, a state permission required for public performances by musicians. As academic training at a Hochschule was considered a prerequisite for the Spielerlaubnis, Becker began to study at the Carl Maria von Weber Hochschule in Dresden. As Becker has related about the impact of Hochschule training on his musical skills, "I noticed later on, to begin, that this wasn't just harassment, but brought about that you actually had well-trained musicians in the GDR [that were], to some extent, better than [those] in the West" (Becker).

The Manfred Ludwig Sextet, which soon after its formation emerged as one of East Germany's leading jazz ensembles, toured in Czechoslovakia and Poland, appeared on a TV and a radio program in Bratislava and was even featured in a Czechoslovakian film (Bratfisch, "Montreux" 126). At that time the Sextet was one of the few jazz groups in the GDR that was given the opportunity to record its music. In 1963 the group recorded an EP for the Amiga label simply entitled Jazz. The album included renditions of Paul Desmond's composition "Take Five," made hugely successful by Dave Brubeck's group, Antonio Carlos Jobim's bossa nova song “Desafinado," Petrowsky's composition "Erinnerungen an Richard" (Memories of Richard), and Eberhard Weise's piece "Skandinavia" (Manfred Ludwig Sextet, Jazz). 


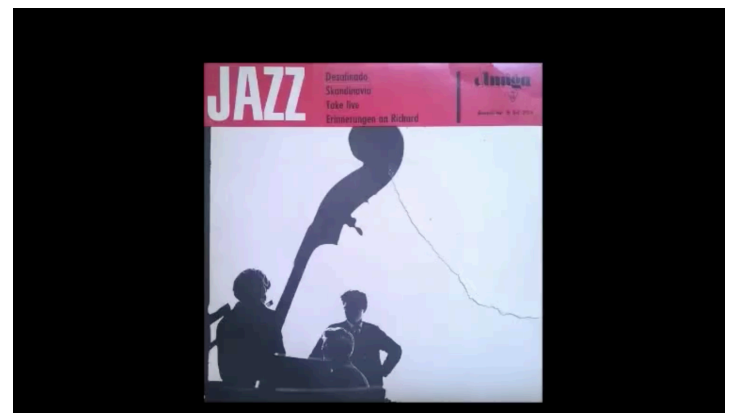

Click image above to listen to: Manfred Ludwig Sextet, Jazz, Amiga, 1963.

In the following year the Manfred Ludwig Sextet recorded an LP for the Amiga label featuring African American contralto Dorothy Ellison, which included well-known songs such as Ray Charles's "Hit the Road Jack" and Billy Strayhorn's iconic “Take the 'A' Train” (Manfred Ludwig Sextet, Jazz mit Dorothy Ellison).

Of great significance for the subsequent course of Petrowsky's musical career was his encounter with pianist Joachim Kühn. Born on March 15, 1944 in Leipzig to a family of artistes, Kühn began to receive piano lessons as a five-year old from Arthur Schmidt-Elsey and began performing in public at the age of six. Influenced by his older brother, clarinetist Rolf Kühn, the young pianist developed a fascination with jazz. Through word of mouth, Petrowsky learned about Joachim Kühn, who during the early 1960s emulated Bobby Timmons's style of playing and was a member of the Werner Pfüller Quintet, a Leipzig-based hard bop group. Petrowsky visited Kühn at home whenever he was in Leipzig and brought his saxophone. As Petrowsky has related about the transformative impetus of these musical encounters,

I received a musical impulse of the first order through my acquaintance with Joachim Kühn. Kühn pursued jazz with a consequence known to me by very few musicians . . Kühn practiced day and night. When I was on a visit to Leipzig, I had to take out the saxophone right away and even though that didn't happen too often I learned a great deal through this interaction. The decisive listening experience at that time was the record "Life Time" by drummer Tony Williams. Together with Joachim Kühn und [bassist] Klaus Koch I practically got into the freer ways of playing after all. (Noglik and Lindner 119-20) ${ }^{5}$

Kühn and Petrowsky performed for the first time together in Leipzig on October 30, 1962, where they played music by Art Blakey's Jazz Messengers among others (Bratfisch, "Leipzig” 141). In December 1964, Kühn put together a trio, which included bassist Klaus Koch and drummer Reinhardt Schwarz; all had been with the Werner Pfüller Quintet. During the mid-1960s, the Kühn Trio performed with Petrowsky on various occasions. Bert Noglik has remarked on Kühn's significance for the history of jazz in the GDR:

Kühn, at the beginning still strongly influenced by role models such as Horace Silver and Bobby Timmons, within a relatively short time span found a personal style and respectively a flow of play predetermined for the group that anticipated much of what would significantly later become common practice in GDR's jazz. This flow of play was, if one disregards stapling themes or rather fragments of themes, already to the greatest extent free associative and no longer conclusively based on the model of eventual American heroes. ("Linden-Blues" 424)

As Noglik has maintained, in the wake of the August 1961 building of the Berlin Wall, "in the cultural policy of the GDR appeared ambivalent streaks—some were handled more rigorously, others more informally" ("Hürdenlauf" 211). During the 1960s, however, the trope of decadence continued to inform the debates around jazz. According to Bratfisch, "the notion of 'decadence' became a central category of totalitarian strategies of exclusion against cultural anomalies" ("So viel Anfang" 44). Furthermore, this notion was oftentimes utilized as a negative foil for the policing of experimental-minded concepts and practices of post-1950s jazz in the GDR. The 1962 edition of Meyer Neues Lexikon, a major encyclopedia, defined decadence as "above all the general cultural decline in capitalist countries due to imperialism's parasitic character." The encyclopedia identified its characteristics as "pessimism, world withdrawal, exaggerated interest in society's outsiders (such as criminals and lunatics), in perversion, diseases, and all things morbid" (qtd. in "So viel Anfang" 44).

The extent to which the above ideologically charged notion made incursions into the lives of experimentally-minded jazz musicians during the mid-1960s manifested on the occasion of a performance of the Kühn Trio with Petrowsky on December 8, 1965. Both Petrowsky and Kühn were among the select artists to perform at the Dresden Hygiene Museum during what Bratfisch has referred to as "the first representative concert of modern GDR jazz with radio and 
TV broadcasts" ("Sechziger Jahre” 89). Promoted by the Konzert- und Gastspieldirektion Dresden, the city's branch of the East German artist agency, and initiated through promoter and radio host Karlheinz Drechsel, the "All-Star Concert" featured more than twenty musicians, among them Petrowsky, who appeared with various lineups. Immediately before their joint performance, Kühn and Petrowsky were confronted with charges of decadence, of which their music was allegedly emblematic. As Petrowsky remembers,

The trio and I were accused of playing decadently. And Kühn said very hurt but very confident as well: 'You can kiss our asses. We don't let anyone meddle with our music anyway. You have no clue.' We said: 'We have our contract and we play.' But we had overlooked the small-printed stipulation that the fee was to be cancelled if the music was deemed decadent by those responsible. And the radio broadcast would get cancelled too. Then we said that they just shouldn't record but we wanted our money and we've had it up to here with them. (Bratfisch, "Montreux" 127)

In his concert review for the popular music magazine Melodie und Rhythmus, one of the few East German periodicals that covered jazz, Drechsel referred to Petrowsky's collaboration with Kühn as the former's "first-time concert performance in the realms of 'free jazz," and called it "the big surprise" (Drechsel 24). Drechsel summarized his impressions regarding the joint Kühn and Petrowsky performance as follows:

The quartet presented avant-garde 'free jazz' and thereby made aware the widely drawn range jazz occupies with us by now. Even though attitudes regarding this current of music-making may be rather varying, it is nonetheless evident that this ambitious group offered high achievements. J. Kühn's harmonic work and the playing of the downright fantastic bass player Klaus Koch astonish again and again ... Even though with E. L. Petrowsky the inclination for longstanding practiced forms of expression instinctively 'filtered through' the Görlitz-based musician succeeded due to his frequently invoked skills to demonstrate the quest for new ways artistically convincingly and honestly. (26)

On May 11, 1966, Kühn performed for the last time in the GDR during a concert in Mittweida with the Ernst-Ludwig Petrowsky Quartet. A week later the pianist participated in the Internationale Jazzkonkurrenz competition in Vienna organized by famed Austrian pianist Friedrich Gulda. With the help of both his brother Rolf Kühn, who had left East Germany in 1950, and Gulda, Joachim Kühn was able to escape from the GDR and moved to Hamburg before he relocated to Paris in $1968 .^{6}$

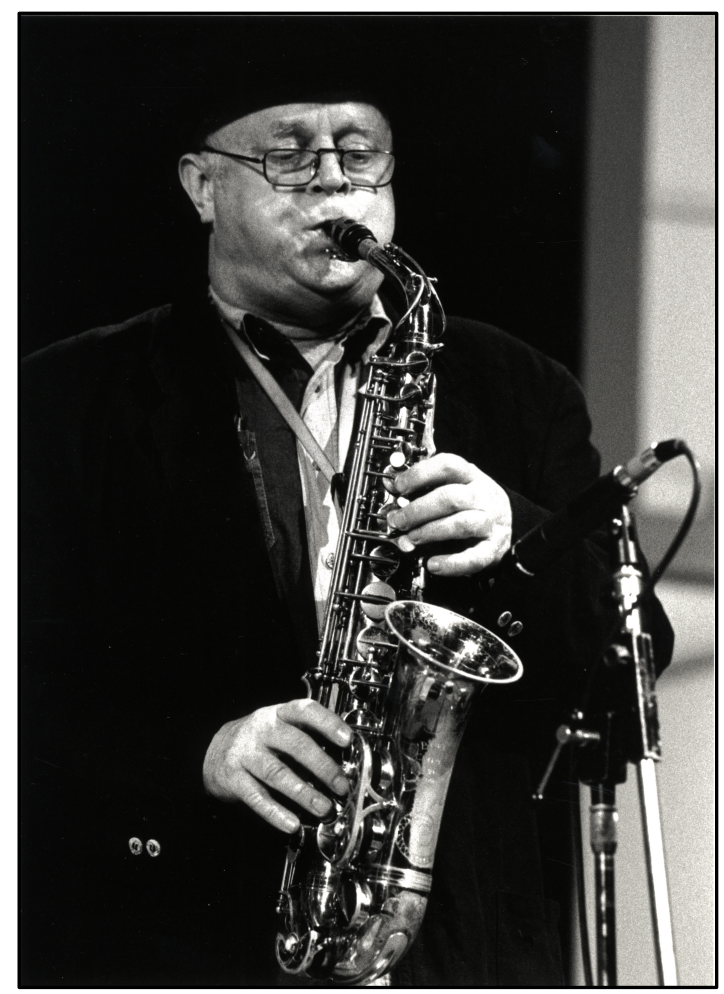

Ernst-Ludwig Petrowsky (Wilfried Heckmann) 
While the Manfred Ludwig-Sextet increasingly played at dancing parties, Petrowsky formed his own group in 1966 as a "band within the band" with members of the sextet. Petrowsky's new group "appeared in public with a quintet and accordingly with a quartet lineup exclusively with jazz music" ("Jazz in der Kammer" No. 9). ${ }^{7}$ He located his music squarely within the realm of African American jazz experimentalism by stating: "My music moves within modern bop, however within this area that has knowledge of Eric Dolphy, Ornette Coleman, Archie Shepp, and Joe Henderson" (Hilbert 291). On December 12, 1966, the Petrowsky Quintet performed in the context of the recently established "Jazz in der Kammer" concert series, where it played compositions by Horace Silver, Sonny Rollins, John Coltrane, and Manfred Schoof alongside original pieces by Petrowsky himself, among them the composition "Variationen zu Joe Henderson." "Jazz in der Kammer" was initiated by a group of jazz enthusiasts, which included dramaturg Martin Linzer, actor Dieter Mann, and landscape gardener Erhard Schmidt, who was the brother of Siegfried Schmidt-Joos (Linzer 93). The group proposed the establishment of a jazz concert series to the artistic and executive directors of the Deutsche Theater and suggested the adjacent Kammerspiele, a modern drama stage established by Max Reinhardt in 1906, as a location for the prospective events.

On November 1, 1965, the series took off with a performance by the Joachim Kühn Trio, which, in Linzer's words, was "the weirdest that was available back then in terms of modern jazz in the GDR" (94). Consistent with the choice of the Deutsches Theater as a location, where productions by dramatist Heiner Müller were staged, the "Jazz in der Kammer" organizers sought to dissociate jazz from popular music and especially dancing music. The program for the first concert outlined the goals behind the series' establishment in the following terms: 'Jazz in der Kammer' is intended to become-the interest of Berlin jazz fans implied-a constant concert series thereby to create a permanent podium for jazz as an art form in Berlin . . . 'Jazz in der Kammer' is intended to serve the advancement and popularization of modern jazz in our republic and exclude any type of commercial dancing music, any pseudo jazz, and unqualified amateur music" (“Jazz in der Kammer" No. 1).

In 1966, composer Andre Asriel published his study Jazz: Analysen und Aspekte, the first comprehensive scholarly account of jazz published in the GDR. Viennese-born Asriel, who drew upon jazz in many of his compositions, was a protégé of Hanns Eisler, who himself had engaged in the East German jazz debate during the 1950s. For instance, in a 1956 interview Eisler stated flatly, "If we concern ourselves with American culture we have to maintain the proportions and in a critical fashion separate the good from the bad even in jazz. Even in the worst depraved jazz something from the rebellion of the oppressed Negroes lingers on" (qtd. in Bratfisch, "So viel Anfang" 42).

In his study, Asriel divided the history of jazz into three distinctive periods, which he denoted as "folksy jazz," "commercial jazz," and "snobbish jazz," while suggesting a transitional period between the first two main periods (1522). He traced the emergence of "snobbish jazz," which he used synonymously for modern or contemporary jazz, to the mid-1930s, while asserting, "that the development, which only set in fully during World War II and then spread to Europe as well, has not been concluded" (22). Furthermore, he identified within "snobbish jazz" both a nonconformist and a conformist tendency, whereupon bebop, hard bop, soul jazz, and free jazz were subsumed under the former category. For Asriel, "snobbish jazz" was "a bourgeois-individualistic music and want[ed] to come across as concert music, however without achieving its wealth of ideas or depth of feeling in general" (23). Asriel's deliberations can be read as a response to the phase-delayed onset of a dynamic that George E. Lewis has described for the US context in the following terms: "By the mid-1950s, black music was being rapidly transformed from a passive source of raw materials for the experiments of pan-European composers to a feared competitor offering a trenchant alternative to the latest products of the pan-European high art tradition" (377-78).

The extent to which Asriel's historical narrative was influenced by the still common charges of formalism was exemplified by his characterization of "snobbish jazz" as shaped by "tendencies towards pessimism and abstraction" (Asriel 22). He identified free jazz as a form of "experimental music," whose practitioners continued the perceived self-indulgence that the bebop movement had initiated (24). In Asriel's reading, however, free jazz largely fell short of what qualified as music: "There is no longer a binding formal scheme, no common harmony and key, even now and then no common tempo. The results are, unsurprisingly, often chaotic (Ornette Coleman) and only become music where the regulatory hand of the jazz composer intervenes in the individualistic collective improvisations (Charlie Mingus)" (177).

When Petrowsky performed in 1966 at a ball, Karl-Heinz Deim, the deputy editor-in-chief for music at the Rundfunk der DDR (Radio of the GDR), approached him. A trained musicologist, Daim was not only a champion of jazz but also a high-ranking SED party official who was frustrated with the amateurish bands utilized for the Radio of the GDR's jazz programs. He sought to ameliorate the situation by establishing a permanent professional jazz ensemble for prospective radio broadcasts. Petrowsky recalls Daim making him the following offer: "Listen, what do you think about that? I want you to be the boss of a group and to pick six people. You can choose them. And then I guarantee you a small fee and that you have a session once a month, where you play compositions or even freely but in any case professionally" (Petrowsky). 
As a result, Petrowsky assembled the radio jazz sextet Ensemble Studio IV, whose significance Rainer Bratfisch has described as an "initial spark for the development of relatively independent styles of playing jazz in the GDR" ("Sechziger Jahre" 88). Led by Petrowsky, the ensemble, which became "the first permanent jazz ensemble of the Radio of the GDR," was named after the broadcasting studio in which the group recorded and included trumpeter Joachim Graswurm, trombonist Hubert Katzenbeier, pianist Eberhard Weise, bassist Klaus Koch, and drummer Wolfgang Winkler (Lange 6). At that time Graswurm, Katzenbeier, Koch, and Winkler were members of the RundfunkTanzorchester Berlin (Radio Dance Orchestra Berlin), whereas Weise was associated with the RundfunkTanzorchester Leipzig (Radio Dance Orchestra Leipzig). Petrowsky, Weise, and Graswurm emerged as the ensemble's primary composers, but Ensemble Studio IV's repertoire also included compositions by Sonny Rollins, Freddie Hubbard, Joe Henderson, and Krzysztof Komeda (8). The ensemble had a monthly day of rehearsals and recorded between 20 and 30 minutes of music on the following day for productions, which were broadcast every six weeks on the Radio of the GDR's “Jazz vor zehn” program (Bratfisch, "Sechziger Jahre" 88).

Petrowsky delineated Ensemble Studio IVs conceptual approach, which he linked to the endeavor to musically come into one's own, in the following terms: "Musically we don't want to tie ourselves to categories but we try to play ourselves. At the same time I view our music as an artistic reflection of contemporary art particularly, of course, as a reflection of the music of our time whereas I include popular music too, all forms of jazz, and non-European music cultures as well” (“Jazz in der Kammer” No. 15).

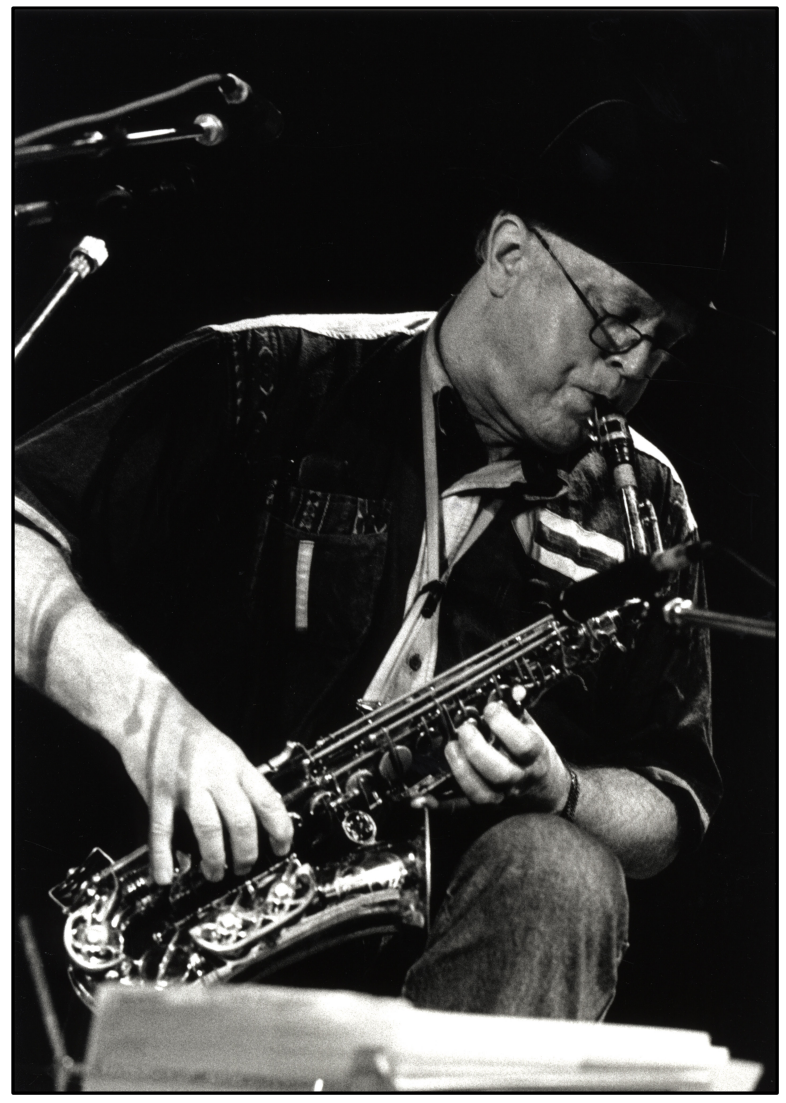

Ernst-Ludwig Petrowsky (Wilfried Heckmann)

A conceptual model for Ensemble Studio IV was the sextet of US composer, theorist, and pianist George Russell. Between 1960 and 1965 Russell made a series of recordings for the Decca, Riverside, and SABA labels, in which he utilized a sextet whose instrumentation was identical to that of the Petrowsky-led ensemble and whose various lineups included multi-reedist Eric Dolphy, trumpeter Don Cherry, trombonist David Baker, and bassist Steve Swallow. ${ }^{8}$ As Petrowsky stated in a 1969 interview regarding Russell's significance for Ensemble Studio IV, "Contemporary jazz knows the most varied instrumental combinations. But eventually a sextet lineup, common in today's jazz, in which for instance the internationally renowned group of George Russell, who lives in Sweden, makes music, seemed very suitable, especially since modern-playing fine musicians were available for these instrumental positions" (Lange 7). Petrowsky was especially intrigued with Russell's "three-part horn section, which with him sounded like nobody else and you didn't feel the need of other parts" and "the slightly different compositions as well," which were informed by 
the composer's Lydian Chromatic Concept of Tonal Organization. ${ }^{9}$ Petrowsky has referred to this moment as characterized "by a compulsory desire for Free Jazz" (Petrowsky).

In June 1968 Ensemble Studio IV was invited to perform at the Montreux Jazz Festival, which was established the previous year. At the 1968 festival, its organizers had asked public service broadcasters in Western and Eastern Europe to dispatch groups to Montreux, whose members had to be less than thirty-five years of age, to participate in a contest. Through the initiative of the Radio of the GDR, Ensemble Studio IV was chosen to represent East Germany in this contest, in which up-and-coming European jazz musicians, who also represented their respective countries, competed for a US tour. As Petrowsky has related in an interview with Bratfisch, before the festival "there were anonymous letters according to which at the very least Klaus Koch and I were supposed to be enticed away by Joachim Kühn, who at that time already was in the West" (Bratfisch, "Montreux" 128). To prevent their eventual escape the Radio of the GDR sent a minder along.

Among the European musicians participating in the competition were Manfred Schoof, Alexander von Schlippenbach, Jan Garbarek, English saxophonist John Surman, and Danish trumpeter Palle Mikkelborg. For the members of Ensemble Studio IV, this was not only their first performance in the West, but also their first in front of a large audience. Petrowsky remembers this performance as particularly dreadful:

A band of a similar nature, the Manfred Schoof Sextet with Alexander von Schlippenbach, therefore awesomely manned, performed and, of course, they played in a very relaxed fashion whereas we could get our beautiful arrangements just barely across. There was a kind of turret, the stage in the middle, and all around the people were seated. I will never forget that. We were, so to speak, 'visible' from all angles. It was stage fright intensifying and the whole situation was psychologically awful. We were only used to playing at dancing parties in our small country at culture or clubhouses. When we got on that stage all colleagues whispered to me: 'I am not playing a chorus today!' (Bratfisch, "Montreux" 128)

Among the critics who attended Ensemble Studio IV's unsuccessful performance was the influential West German jazz critic, impresario, and record producer Joachim-Ernst Berendt. In his review, he correlated Ensemble Studio IV's perceived uptight way of playing with the state socialist system by quoting from a personal letter written to him by the Radio of the GDR's editor-in-chief Wilhelm Penndorf. In this letter Penndorf posited a distinctive path of development for jazz in state socialist countries, which supposedly deviated from that in capitalist countries. According to Berendt, Penndorf stated, "in principle we have independent conceptual thoughts on the advancement of jazz music according to socialist conditions" (qtd. in Berendt 248). In doing so, Penndorf voiced ideas that were consistent with SED governmental cultural policies that, as Irmgard Jungmann has suggested, sought "to establish a distinctive popular music, which was in accordance with the demands of a socialist conceived social responsibility" (154). Taking a cue from Penndorf's deliberations, Berendt stated sardonically:

At that time everyone who saw that letter laughed about it. Meanwhile I wonder if it does not contain a sad truth. These musicians played just as 'unrelaxed' and self-conscious as the above quoted sentences are phrased. One of the Scandinavian critics reckoned: 'One has to live in an uptight fashion in order to play in an uptight fashion.' Under these circumstances it would have been better if Ernst-Ludwig Petrowsky had just played with a rhythm section. Then, unimpeded by arrangements and presentation issues, he could have just given proof of his musical and technical skills, which he possesses without a doubt, and by that outperformed some other of the numerously existing alto saxophonists (248).

In April and May 1969, Ensemble Studio IV was provided with an opportunity to record an album for the Amiga label. Entitled Jazz mit dem Ensemble Studio 4, the album contained primarily compositions by Petrowsky and Weise (Ensemble Studio IV). In the wake of the album's release, however, the palpable lack of acceptance of contemporary jazz practices on the part of audiences and fellow musicians became an extraordinary challenge. Culture secretary Klaus Gysi voiced the extent to which jazz musicians during the late 1960s could still be categorized as potentially subversive. Gysi identified "the beautiful euphoria of a state of intoxication" as a "basic means of imperialist manipulation" and identified music as "one of its major instruments" (qtd. in Wicke 73). As Petrowsky recalls: "Through the radio network we sometimes had events-among others in Dresden at the Keller am Weißen Hirsch, where usually [popular band leader] Theo Schumann played. There were hardly any people. And those few were appalled. That gave them the creeps. At a major event in Leipzig, with the radio network as well, together with Günter Hörig, not even the Hörig folks were looking at us. They thought we were as mad as a hatter" (Bratfisch, "Montreux" 129). 


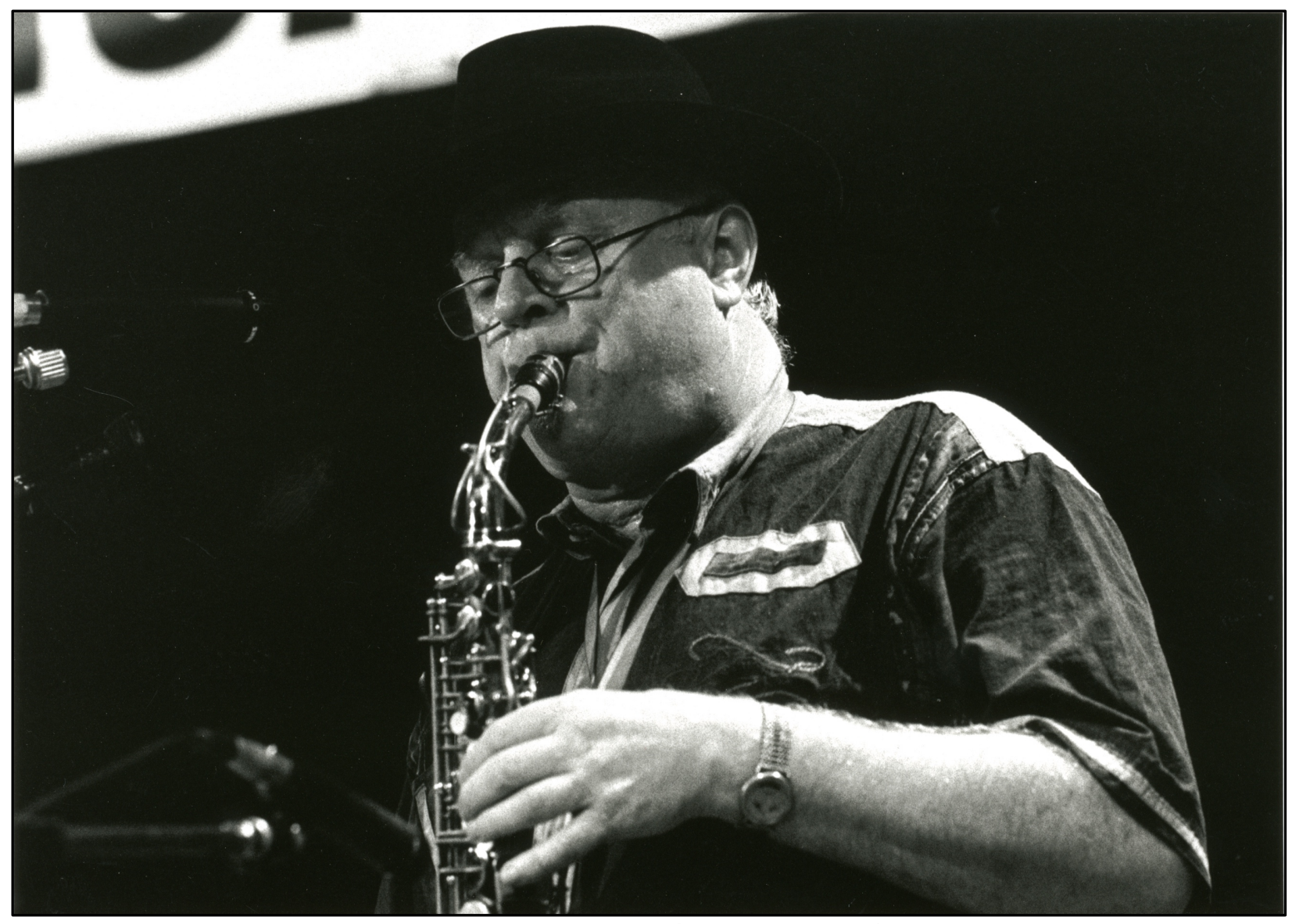

Ernst-Ludwig Petrowsky (Wilfried Heckmann)

Petrowsky's experiences defy the convenient upholding of a US-Europe binary as well as simplistic East-West, oppression-freedom binaries that continue to inform historiographies of post-1950s jazz. Moreover, they reveal that the European jazz experimentalism movement was shaped by a transnational dynamic, which irrespective of markers such as nation and race, was not confined by a pan-European imaginary. Petrowsky's engagement with the music of African-American experimentalists such as Tony Williams and George Russell points to the salience of East Germany as an important site for extensions of black experimentalism despite its lack of association with black cultural traffic. The transpositions and adaptations of black musical methods, concepts, and practices in East Germany became prime sites for contestations as well as the formation of tension-fraught definitions of cultural and national identities. In the case of Petrowsky, association with rather than dissociation from black musical knowledge has been of critical importance for informing his own concepts and practices, which brings to mind Édouard Glissant's notion of the construction of identity in relation not in isolation. Petrowsky's sustained engagement with African-American musical knowledge, moreover, highlights the impossibility of mapping sonic identities onto national and ethnic identities. As Petrowsky has remarked in terms of his self-positioning, "it was never even much later, a matter of somehow being European, or this infamous word 'GDR jazz.' There is only 'jazz in the GDR.' I have said before that it is characterized especially by a certain rhythmic bumpiness. East German jazz was even further removed, in fact inaccessible, from the source, which settled in with the Americans in West Germany" (Petrowsky).

\section{Notes}

${ }^{1}$ Author's interview with Ernst-Ludwig Petrowsky in Berlin, 28 Feb. 2011. All translations, unless noted otherwise, are my own. All information pertaining to Petrowsky's biography is derived from this interview.

${ }^{2}$ For a discussion of Komeda's significance, see Ritter 29-49.

${ }^{3}$ For an in-depth discussion of Rudorf's 1950s jazz campaign, see also Poiger, Jazz, Rock, and Rebels 150-62. 
${ }^{4}$ The information pertaining to Heinz Becker's biography is derived from a personal interview that I conducted with him on 7 Sept. 2011 in Gelting, Germany.

${ }^{5}$ Petrowsky is referring here to Tony Williams's 1964 debut album Life Time. The album featured the line-up of Sam Rivers, Herbie Hancock, Bobby Hutcherson, Ron Carter, Richard Davis, and Gary Peacock. See Anthony "Tony" Williams, Life Time.

${ }^{6}$ For an account of Joachim Kühn's escape from East Germany, see Sickert 114-15.

${ }^{7}$ I am indebted to Wolf-P. "Assi" Glöde, who kindly provided me with copies of the "Jazz in der Kammer" concert programs.

${ }^{8}$ For a discussion of Russell's various sextets, see Heining 153-193.

${ }^{9}$ For a discussion of Russell's Lydian Chromatic Concept, see Monson 149-68.

\section{Works Cited}

Asriel, Andre. Jazz: Analysen und Aspekte. VEB Lied der Zeit Musikverlag, 1966.

Becker, Heinz. Interview. By Harald Kisiedu. 7 Sept. 2011.

Berendt, Joachim-Ernst. “Jazzfestival in Montreux." Jazz Podium, vol. 17, no. 8, Aug. 1968, pp. 248-9.

Bratfisch, Rainer. "'Aber Montreux war fürchterlich': Interview mit Ernst-Ludwig Petrowsky." Freie Töne: Die Jazzszene in der DDR, edited by Rainer Bratfisch, Ch. Links Verlag, 2005, pp. 125-36.

---. "Die sechziger Jahre: Jazz in der (ein) geschlossenen Gesellschaft." Freie Töne: Die Jazzszene in der DDR, edited by Rainer Bratfisch, Ch. Links Verlag, 2005, pp. 83-92.

---. "So viel Anfang war nie: Eine Spurensuche nach 1945." Freie Töne: Die Jazzszene in der DDR, edited by Rainer Bratfisch, Ch. Links Verlag, 2005, pp. 17-30.

Churchill, Winston S. His Complete Speeches: 1897-1963. Edited by Robert Rhodes James, vol. 7: 1943-49, Chelsea House Publishers in association with R. R. Bowker Company, 1974.

Drechsel, Karlheinz. “Jazzkonzert mit DDR-Solisten.” Melodie und Rhythmus, no. 9, May 1966, pp. 24-8.

Ensemble Studio IV. Jazz mit dem Ensemble Studio 4. Amiga, 1969.

Heining, Duncan. George Russell: The Story of an American Composer. Scarecrow Press, 2010.

Hilbert, Helmut. "Ernst-Ludwig Petrowsky: Moderner Bop mit Free-Impulsen." Jazz Podium, vol. 16, no. 10, Oct. 1967, p. 291.

Jäger, Manfred. Kultur und Politik in der DDR: 1945-1990. 1994. Edition Deutschland Archiv, 1995.

“Jazz in der Kammer." Playbill No. 1, Nov.1, 1965.

---. Playbill No. 9, Dec. 12, 1966.

---. Playbill No. 15, Feb. 5, 1968.

Jost, Ekkehard. Jazzgeschichten aus Europa. Wolke Verlag, 2012. 
Jungmann, Irmgard. Kalter Krieg in der Musik: Eine Geschichte deutsch-deutscher Musikideologien. Böhlau Verlag, 2011.

Knepler, Georg. “Musik, ein Instrument der Kriegsvorbereitung.” Musik und Gesellschaft, vol. 2, 1951, pp. 56-8.

Lange, Wolfgang. "Man spricht von Luten und Studio IV." Melodie und Rhythmus, no. 3, 1969, pp. 6-9.

Lewis, George E. A Power Stronger than Itself: The AACM and American Experimental Music. U Chicago P, 2008, pp. 61-80.

Linzer, Martin. “Jazz in der Kammer' 1965-1990.” Freie Töne: Die Jazzszene in der DDR, edited by Rainer Bratfisch, Ch. Links Verlag, 2005, pp. 93-108.

Lücke, Martin. "The Postwar Campaign against Jazz in the USSR (1945-1953)." Jazz behind the Iron Curtain, edited by Gertrud Pickhan and Rüdiger Ritter, Peter Lang, 2010, pp. 83-98.

Malycha, Andreas. Geschichte der DDR. Informationen zur politischen Bildung, vol. 312, Mar. 2011.

Manfred Ludwig Sextet. Jazz. Amiga, 1963.

---. Jazz mit Dorothy Ellison \& dem Manfred Ludwig-Sextett. 1965. ITM Records, 2005.

Monson, Ingrid. "Oh Freedom: George Russell, John Coltrane, and Modal Jazz." In the Course of Performance: Studies in the World of Musical Improvisation, edited by Bruno Nettl and Melinda Russell, U Chicago P, 1998, pp. 149-68.

Noglik, Bert. "Hürdenlauf zum freien Spiel: Ein Rückblick auf den Jazz der DDR." Jazz in Deutschland: Darmstädter Beiträge zur Jazzforschung, edited by Wolfram Knauer, vol. 4, Wolke Verlag, 1996, pp. 205-21.

---. Jazzwerkstatt international. Verlag Neue Musik, 1981.

---. "Vom Linden-Blues zum Zentralquartett: Fragmentarisches zur Entwicklung des Jazz in der DDR.” That's Jazz: Der Sound des 20. Jahrhunderts, edited by Klaus Wolbert, Verlag Erwin Bochinsky, 1988, pp. 421-32.

Noglik, Bert, and Heinz-Jürgen Lindner. Jazz im Gespräch. Verlag Neue Musik, 1978.

Petrowsky, Ernst-Ludwig. Interview. By Harald Kisiedu. 28 Feb. 2011.

Poiger, Uta G. Jazz, Rock, and Rebels: Cold War Politics and American Culture in a Divided Germany. U California $P, 2000$.

---. "Searching for Proper New Music: Jazz in Cold War Germany." German Pop Culture: How "American" Is It?, edited by Agnes C. Mueller, Ann Arbor: U Michigan P, 2004, pp. 83-95.

Prieberg, Fred K. Musik im anderen Deutschland. Verlag Wissenschaft und Politik, 1968.

Rauhut, Michael. Beat in der Grauzone: DDR-Rock 1964 bis 1972: Politik und Alltag. BasisDruck, 1993.

---. "The Voice of the Other America: African-American Music and Political Protest in the German Democratic Republic." Between the Avant-Garde and the Everyday: Subversive Politics in Europe from 1957 to the Present, edited by Timothy Brown and Lorena Anton, Berghahn Books, 2011, pp. 92-108.

Ritter, Rüdiger. “Jazzmusiker als 'Gründungsväter' für nationale Jazzszenen? Krzysztof Komeda und der polnische Jazz.” Albert Mangelsdorff: Tension/Spannung: Darmstädter Beiträge zur Jazzforschung, edited by Wolfram Knauer, vol. 11, Wolke Verlag, 2010, pp. 29-49.

Rudolf, Reginald (Reginald Rudorf). "Für eine frohe, ausdrucksvolle Tanzmusik." Musik und Gesellschaft, vol. 2, Aug. 1952, pp. 247-52. 
Rudorf, Reginald (see also Rudolf, Reginald). "Die Tanzmusik muß neue Wege gehen." Musik und Gesellschaft, vol. 4, part. 2, Mar. 1954, pp. 92-5.

Schmidt-Rost, Christian. "Heiße Rhythmen im Kalten Krieg: Swing und Jazz hören in der SBZ/DDR und der VR Polen (1945-1970)." Zeithistorische Forschungen/Studies in Contemporary History, vol. 8, no. 2, 2011, http://www.zeithistorische-forschungen.de/16126041-Schmidt-Rost-2-2011.

Sickert, Maxi. Clarinet Bird: Rolf Kühn—Jazzgespräche. Christian Broecking Verlag, 2009.

Staritz, Dietrich. Geschichte der DDR. Suhrkamp, 1996.

Tompkins, David G. Composing the Party Line: Music and Politics in Early Cold War Poland and Germany. Purdue UP, 2013.

Weber, Hermann. Geschichte der DDR. Deutscher Taschenbuch Verlag, 1999.

Wicke, Peter. "Rock 'n' Roll im Stadtpark: Von einer unerlaubten Vision in den Grenzen des Erlaubten." Jeans, Rock und Vietnam: Amerikanische Kultur in der DDR, edited by Therese Hörnigk and Alexander Stephan, Theater der Zeit and Literaturforum im Brecht-Haus Berlin, 2002, pp. 61-80.

Williams, Anthony “Tony”. Life Time. 1964. Blue Note, 1995.

Zhdanov, Andrei. Speech at the founding of the Cominform (a Communist International Organization), Sept. 1947. http://educ.jmu.edu/ vannorwc/assets/ghist\%20102-150/pages/readings/zhdanovspeech.html. 